\title{
PARADIGMA FILSAFAT POSITIVISME HUKUM DI INDONESIA
}

\author{
Ramlani Lina Sinaulan
}

Universitas Jayabaya, Jakarta | Jl. Pulomas Selatan Kav. 23, Pulo Mas selatas,

Pulo Gadung, Jakarta Timur

linasinaulan@gmail.com

\begin{abstract}
The science of law has a unique and distinctive character where every country has its own peculiarities. The development of legal science is influenced by the views of the jurists. In issuing legal opinions, the jurists are often influenced by their education and scholarship that will always be subjective depending on the paradigm used. Nevertheless, Indonesia, through the fourth paragraph of the Preamble of the 1945 Constitution of RI affirmed that Pancasila is as a paradigm in all life of state and society. Pancasila is the only paradigm (philosophy) of law that is recognized in some legislations. Pancasila is one of the elements that characterize the uniqueness of the Indonesian state. As a positive science, the science of law contains a normative nature in practice based on social science strategy. So that, the science of law aims to providing alternative solutions to solve concrete social problems. The use of social science strategy is not intended to change the normative nature of the science of law, but adopts Pancasila as the legal paradigm (philosophy).
\end{abstract}

Keywords: Paradigm, philosophy, Pancasila, science of law

Abstrak: IImu hukum memiliki sifat yang unik dan khas dimana setiap negara memiliki kekhasan sendiri yang mempengaruhi perkembangan ilmu hukumnya. Perkembangan ilmu hukum dipengaruhi oleh pandangan para ahli hukum di dalamnya. Ilmuwan hukum dalam mengeluarkan pendapat dipengaruhi oleh pendidikan dan keilmuannya dan akan selalu bersifat subjektif bergantung pada paradigma yang digunakan. Namun demikian, Indonesia melalui Alinea IV Pembukaan UUD RI 1945 menegaskan bahwa Pancasila sebagai paradigma dalam seluruh kehidupan bernegara dan bermasyarakat. Pancasila merupakan satu-satunya paradigma (filsafat) hukum yang diakui dan dinormatifkan pengakuan tersebut dalam beberapa peraturan perundang-undangan. Pancasila adalah salah satu unsur yang mencirikan keunikan dan kekhasan dari negara Indonesia. Adapun ilmu hukum sebagai ilmu 
positif mengandung sifat normatif yang dalam pengembanan praktisnya bergerak berdasarkan strategi ilmu sosial, sehingga ilmu hukum memiliki tujuan memberikan solusi alternatif penyelesaian masalah konkret dalam masyarakat. Penggunaan strategi ilmu sosial tersebut bukan dimaksudkan untuk mengubah sifat normatif dari ilmu hukum, namun mengadopsi Pancasila sebagai paradigma (filsafat) hukum.

Kata Kunci: Paradigma, filsafat, Pancasila, IImu Hukum

\section{Pendahuluan}

Perdebatan ilmu hukum dan ilmu sosial, tidak pernah berhenti berpolemik dalam hal penentuan metode pada bidang ilmu pengetahuan geisteswissenschaften ${ }^{1}$ dan naturwissenschaften ${ }^{2}$. Permasalahan-permasalahan tersebut sedikit banyak mendapat pengaruh langsung dari tarik menarik antar paradigma (filsafat) hukum yang menjadi kerangka dasar umum dalam melaksanakan penalaran hukum terhadap suatu permasalahan sosial.

Semenjak dipergunakannya paradigma (filsafat) positivisme hukum, khususnya dalam ranah pengembangan ilmu hukum praktis oleh para penegak hukum, telah menepiskan daya nalar dan hilangnya rasa kemanusiaan terhadap manusia-manusia yang memiliki persoalan-persoalan sosial. Sebagai suatu paradigma yang tidak tumbuh dan berkembang dari nilai-nilai yang hidup dalam masyarakat Indonesia, namun memperoleh pengakuan secara de facto oleh para penegak hukum, menjadi antinomi dan anomali hukum yang terus tercipta, terpelihara dan tak terselesaikan. Pancasila, baik sebagai cita hukum (rechtsidee) maupun cita negara (staatsidee), tidak mengalami pendistilasian dengan baik oleh pembentuk undang-undang. Sehingga sebagai suatu philosophische grondslag (filsafat/filosofi dasar bangsa Indonesia), Pancasila hanya berada dalam tataran ide dan wacana.

\footnotetext{
I Geisteswissenschaften adalah ilmu-ilmu budaya atau ilmu-ilmu yang objeknya adalah hasil atau ekspresi roh manusia. Yang termasuk geisteswissenschaften adalah ilmu-ilmu sosial ataupun ilmuilmu human/kemanusiaan seperti IImu Hukum, Ekonomi, Sejarah, Sosiologi, Antropologi sosial/budaya, Psikologi (untuk sebagian), IImu Bahasa, dan Ilmu Komunikasi.

${ }^{2}$ Naturwissenschaften adalah ilmu kealaman yang objeknya benda-benda fisik, seperti IImu Fisika, Kimia dan Biologi, serta ilmu-ilmu khusus lain yang merupakan pengkhususan lebih lanjut ataupun cabang-cabang dari ilmu-ilmu tersebut, misalnya Fisiologi, Anatomi dan sebagainya.
} 
Ketika memasuki masa pelaksanaan Seminar Hukum Nasional II Tahun 1968, dengan agenda pembahasan R-KUHP Buku I, yang telah digagas mulai dari Seminar Hukum Nasional I Tahun 1963, Moeljatno melontarkan suatu kritik berupa pertanyaan melalui makalahnya, yaitu atas dasar atau asas-asas apakah hendaknya hukum pidana Indonesia dibangun?. ${ }^{3}$ Pertanyaan tersebut ketika dipahami pada saat ini, memunculkan pertanyaan pula yaitu: apakah yang dimaksud oleh Moeljatno pada saat itu berkaitan dengan digunakannya frase 'asas-asas' adalah merujuk kepada klasifikasi dari suatu sistem nilai (normaasas-nilai), ataukah 'dasar' dari keseluruhan sistem nilai, yaitu nilai itu sendiri.

Dalam memahami ungkapan tersebut, harus direkonstruksikan suasana kebatinan dan kondisi hukum pada saat ungkapan tersebut diucapkan, karena ungkapan tersebut telah mengalami reduksi makna dari ungkapan sebagai hasil olah fikiran, kemudian menjadi teks. Gejala pertama, semenjak tahun 1963 pada saat Seminar Hukum Nasional I yang memunculkan RKUHP versi 1964, hingga dilaksanakan Seminar Hukum Nasional II tahun 1968, artinya R-KUHP versi 1964 telah berjalan selama 4 (empat) tahun dan masih dalam pembahasan sekitar Buku I RKUHP; kedua, adanya ketimpangan antara das sollen (norma) dan das sein (peristiwa konkrit) yang lebih banyak disebabkan karena ketidaksesuain nilai dan norma yang terkandung di dalam hukum positif pada saat itu; ketiga, diungkapkan oleh Roeslan Saleh, murid dari Moeljatno, dimana panitia untuk membentuk KUHP terlalu sedikit pengertiannya tentang paham hukum rakyat Indonesia sendiri, sehingga KUHP tersebut kurang sesuai dengan kesadaran hukum rakyat Indonesia; keempat, semangat reformasi hukum (legal reform) yang diwacanakan semenjak Seminar Hukum Nasional I pada tahun 1963, memandang bahwa perlu adanya perubahan sistem hukum sebagai akibat dari diproklamirkannya

${ }^{3}$ Barda Nawawi Arief, RUU KUHP Baru. Sebuah Restrukturisasi/Rekonstruksi Sistem Hukum Pidana Indonesia, (Semarang: Badan Penerbit UNDIP, 20 I2), 8. 
kemerdekaan melalui Proklamasi Kemerdekaan dan pengesahan UUD 1945. Bahwa transformasi nilai dan norma hukum dari Belanda ke dalam sistem kemasyarakatan yang ada melalui kekuasaan dan kekuatan militer, telah merubah sistem hukum yang ada menjadi tertinggal.

Melalui penelurusan terhadap suasana, keadaan dan kondisi saat itu, maka menurut penulis, ungkapan Moeljatno lebih mengarah kepada pertanyaan atas ketiadaan landasan falsafah sebagai dasar pembentuk hukum di Indonesia. Landasan falsafah memiliki arti penting dalam suatu proses pembentukan hukum. Secara sederhana, dapat dikatakan bahwa setiap pengemban hukum selalu bekerja berdasarkan kerangka dasar umum (general basic framework) dan asumsi yang merupakan pedoman bagi setiap kegiatan ilmiahnya.

Dalam mempersoalkan suatu masalah hukum, hendaknya pengkajiannya dimulai dari kegiatan ilmiah Ilmu Hukum yaitu dengan melakukan refleksi kefilsafatan. ${ }^{4}$ Refleksi kefilsafatan tentang Ilmu Hukum yang lengkap akan mempersoalkan aspek ontologi, epistemologi dan aspek aksiologi dari Ilmu Hukum. Penelaahan terhadap tiga aspek tersebut akan menentukan keberadaan dan karakter keilmuan dari Ilmu Hukum yang akan berimplikasi pada cara pengembanan Ilmu Hukum (pengembanan hukum teoretis) dan praktis Ilmu Hukum (pengembanan hukum praktis) dalam kenyataan kehidupan kemasyarakatan. Sebab, pandangan tentang Ilmu Hukum akan mempengaruhi bentuk dan cara pendidikan (tinggi) hukum, dan cara berfikir serta cara berkarya para ahli hukum yang dihasilkannya.

Terhadap hal tersebut, penulis mengutip pendapat dari Mochtar Kusuma-Atmadja yang disitir oleh Otje Salman, bahwa hukum yang dibuat harus sesuai atau memperhatikan kesadaran

\footnotetext{
${ }^{4}$ Bernard Arief Sidharta, Refleksi Tentang Struktur IImu Hukum Sebuah Penelitian Tentang Fundasi Kefilsafatan dan Sifat Keilmuan IImu Hukum Sebagai Landasan Pengembangan IImu Hukum Nasional Indonesia, (Bandung: Mandar Maju, 2009), 9- I 0.
} 
hukum masyarakat. ${ }^{5}$ Sebagaimana ditegaskan oleh Jan Gijssels dan Mark van Hoecke, dimana hukum itu adalah dan harus merupakan suatu pencerminan dari suatu peradaban (beschaving). ${ }^{6}$ Artinya, pembentukan peraturan perundang-undangan pidana hendaknya tidak bersifat individualistik, yang dianut dan ditularkan melalui kolonialisme, namun kolektif kemasyarakatan, karena hukum merupakan gejala sosial.

Berdasarkan uraian di atas, maka penulis memandang adanya suatu permasalahan hukum yang kiranya sangat patut dan layak untuk dikaji secara mendalam, yaitu apakah penggunaan Pancasila sebagai suatu paradigma (filsafat) hukum telah tepat untuk menggeser hegemoni paradigma (filsafat) positivisme hukum dalam proses pembaharuan hukum pidana di Indonesia.

\section{Berkembangnya Paradigma Rasional di Indonesia}

Semenjak memperoleh kemerdekaan dari kolonialisme, maka telah terjadi kesepakatan secara nasional untuk meninggalkan sistem hukum warisan kolonialisme secara utuh, termasuk semua produk turunannya, sebagaimana termuat di dalam proklamasi. Namun demikian, kehidupan bernegara pada saat itu tidak serta merta dapat menggunakan sistem hukum yang sesuai dengan keinginan bangsa Indonesia.

Kesulitan-kesulitan tersebut merupakan akibat dari model pendidikan hukum yang memang diwariskan secara doktrinal kepada para yuris di Indonesia. Selain itu, perubahan drastis akan menyebabkan kekosongan hukum. Dalam ranah dogmatika hukum (praktik hukum), hampir semua elemen terjebak kepada comfort zone (zona nyaman), sehingga momentum untuk merubah budaya hukum menjadi terlewatkan. Berhasilnya politik penjajahan untuk memarginalkan sistem hukum yang pernah ada

\footnotetext{
${ }^{5}$ Otje Salman, Filsafat Hukum (Perkembangan dan Dinamika Masalah), (Bandung: Refika Aditama, 2010), 28.

${ }^{6}$ Jan Gijssels dan Mark van Hoecke, Apakah Teori Hukum Itu?, terj. Bernard Arief Sidharta, Penerbitan Tidak Berkala Nomor 3, Seri Dasar-Dasar Ilmu Hukum Nomor 3, (Bandung: Laboratorium Hukum Fakultas Hukum Universitas Katolik Parahyangan, 200 I), 16.
} 
yaitu hukum adat dan hukum Islam selama masa penjajahan, menjadikan para yuris dan praktisi hukum menjadi tidak familier terhadap sistem hukum yang pernah ada tersebut. Sisi lain kelemahan yang ada dalam mengubah paradigma hukum tersebut adalah minimnya referensi dan/atau kajian-kajian ilmiah yang dituangkan dalam bentuk tulisan untuk disosialisasikan.

Para ahli-ahli hukum pada masa lalu hingga masa kini sudah seringkali mempertanyakan tentang perkembangan paradigma rasional yang bersifat positivistik-legalistik yang masuk ke Indonesia yang selalu dipertentangkan dengan hukum yang hidup (the living law) di Indonesia. Menurut Khudzaifah Dimyati \& Kelik Wardiono, berakarnya paradigma rasional tersebut disebabkan karena 5 (lima) faktor, yaitu?:

1. Adanya politik hukum dari pemerintah kolonial Hindia Belanda, untuk memberlakukan sistem hukum di tanah jajahan yang sama dengan sistem hukum yang berlaku di negaranya;

2. Upaya dari pemerintah Hindia Belanda untuk menjauhkan segala unsur-unsur ajaran Islam dan ke-Islam-an dari kehidupan negara, ketatanegaraan, masyarakat dan hukum;

3. Adanya keinginan dari pemerintah kolonial untuk mengubah struktur ekonomi di Hindia Belanda menjadi sistem liberalkapitalistik dan mengintegrasikan ekonomi di Hindia Belanda dalam perekonomian internasional;

4. Kemenangan dari kelompok pen-studi hukum antara yang menyarankan agar tata hukum Indonesia berlanjut saja dengan tata hukum yang telah dibangun sejak zaman pemerintahan kolonial Hindia Belanda dengan kelompok yang menganjurkan agar di Indonesia dibangun tata hukum yang benar-benar baru, ataupun kelompok yang hendak memperjuangkan terwujudnya hukum nasional dengan cara mengangkat hukum rakyat, yaitu hukum adat sebagai hukum, di masa-masa awal kemerdekaan Indonesia;

7 Khudzaifah Dimyati \& Kelik Wardiono, Paradigma Rasional Dalam IImu Hukum. Basis Epistemologis Pure Theory of Law Hans Kelsen, (Yogyakarta: Genta Publishing, 20I4), vi. 
5. Kebutuhan untuk menyiapkan rechtsambtenar (hakim atau panitera) yang di satu sisi dapat memahami hukum yang berkembang menurut konsep-konsep dan prosedur yang ditradisikan dalam budaya Eropa, dan di sisi lain memiliki kemampuan dan kepekaan untuk mengenal dengan penuh penghayatan alam budaya simbolik bangsanya sendiri.

Bernard Arief Sidharta pun melakukan penelitian terhadap terhalangnya hukum asli Indonesia muncul ke permukaan, yang hasilnya memiliki kemiripan dengan apa yang telah diungkapkan di atas, dimana ditegaskan faktor-faktor penyebab kesulitan tersebut antara lain 8 :

1. Perang kemerdekaan sebagai akibat usaha Belanda untuk mengembalikan kekuasaan kolonial di Indonesia;

2. Secara etnis, bangsa Indonesia sangat heterogen dengan berbagai adat istiadat dan sub-kulturnya, dan tersebar pada suatu wilayah kepulauan yang sangat luas. Intensitas proses interaksi antar suku pada masa kolonial sangat lemah yang menyebabkan proses unifikasi hukum secara alamiah praktis tidak terjadi;

3. Tata hukum kolonial yang harus diganti dengan tata hukum nasional sudah cukup lama menguasai kehidupan (hukum) di Indonesia;

4. Politik hukum kolonial, yang berakar dalam politik kolonial pada umumnya yang memfungsikan wilayah jajahan dengan potensinya hanya sebagai penopang kepentingan ekonomi negara induk, telah menyebabkan Bangsa Indonesia dan hukum adatnya pada masa kolonial itu relatif terasing dari pergaulan dan perkembangan pada tingkat mondial (global). Hal ini menyebabkan Bangsa Indonesia dan hukum adatnya secara langsung dihadapkan pada berbagai masalah modern yang sudah amat jauh perkembangannya dan sangat kompleks;

${ }^{8}$ Bernard Arief Sidharta, Refleksi Tentang Struktur IImu Hukum..., 4. 
5. Pada saat kemerdekaan diproklamasikan, jumlah sarjana hukum yang kompeten, yang memiliki kemampuan legislative drafting, masih terlalu sedikit untuk mampu dalam waktu singkat menghasilkan berbagai perangkat kaidah hukum positif nasional yang diperkirakan jumlahnya, pada saat setelah proklamasi, hanya berkisar 200 orang sarjana hukum;

6. Perkembangan ilmu dan teknologi yang terjalin dengan pertambahan penduduk, perkembangan ekonomi dan perdagangan adalah merupakan faktor yang paling mendasar dan memiliki jangkauan yang luas dalam memberikan pengaruh secara langsung terhadap perkembangan hukum, kehidupan hukum dan kebutuhan hukum.

Kesulitan-kesulitan tersebut telah dideskripsikan oleh $\mathrm{R}$. Soepomo dengan memberikan penjelasan sebagai berikut ${ }^{9}$ :

"Kemerdekaan politik hanyalah suatu jembatan yang jauh di seberangnya, kami harus membangun kembali masyarakat kami. Sejak saat itu, dan selanjutnya, memanglah suatu kewajiban yang terpenting bagi para pemimpin untuk membuat kemerdekaan itu menjadi berarti bagi rakyat jelata. Masyarakat kolonial telah ditinggalkan kepada kami oleh kekuasaan kolonial Belanda dahulu. Dengan berakhirnya masa kolonial itu, kami dihadapkan kepada masalah mengubah dan membaharui Indonesia, yang berarti: meruntuhkan tata tertib masyarakat yang lampau, dan menciptakan ukuran-ukuran baru, berdasarkan kebutuhankebutuhan nasional dari Bangsa Indonesia, disesuaikan dengan syarat-syarat hidup modern."

R. Soepomo hendak menggambarkan adanya suatu usaha yang keras untuk merubah budaya hukum yang mengakar di masyarakat Indonesia, khususnya budaya hukum pada institusi penegak hukum saat itu. Hal ini merupakan sesuatu hal yang sulit untuk dicapai. Perubahan budaya hukum tersebut bukan saja yang ada pada institusi negara, namun juga perubahan cara pandang masyarakat terhadap geraknya institusi tersebut. Kaitannya

\footnotetext{
${ }^{9}$ R. Soepomo, Bab-Bab Tentang Hukum Adat, (Jakarta: Balai Pustaka, 20 I3), I -2.
} 
dengan hal tersebut, pengaruh perkembangan terhadap penghormatan hak asasi manusia dalam taraf internasional turut mempengaruhi kehidupan bernegara.

Sebagai akibat dari pengaruh hubungan-hubungan hukum yang telah terjadi secara meluas, bahkan melewati batas-batas negara, atau lebih dikenal dengan istilah globalisasi, pengaruh filsafat hukum dalam membentuk politik hukum dan sistem hukum suatu negara, dapat pula dikatakan sebagai salah satu unsur yang mempengaruhi pola pikir dalam pembentukan hukum. Sebagaimana dijelaskan oleh Sunaryati Hartono, bahwa terdapat falsafah-falsafah hukum yang mempengaruhi pembangunan hukum nasional baik masa lalu maupun saat ini. ${ }^{10}$

\section{Pancasila dan Manusia Indonesia}

Cita negara dan tujuan bernegara tiap bangsa adalah sesuatu yang unik dan khas sehingga tidak pernah sama bagi setiap bangsa. ${ }^{11}$ Struktur ketatanegaraan yang dinegasikan dari tiap cita negara dan tujuan negara yang berbeda, dengan sendirinya juga akan selalu berbeda bagi setiap bangsa. Jadi, untuk mencapai tujuan negara sebagai tujuan bersama bangsa perlu dilakukan pengorganisasian kekuasaan negara yang bertitik tolak dari cita negara.

Kebutuhan akan peraturan perundang-undangan dalam konteks Negara Hukum menjadi sangat penting. Hal tersebut dikarenakan, negara dijalankan oleh manusia-manusia dan bukan oleh mesin. Dengan demikian, dalam praktik sehari-hari, segala tindakan negara dilakukan oleh manusia-manusia. Dan karena tak ada manusia yang tak bercacat, seluruh pekerjaannya pun tidak sempurna. Maka, jikalau orang yang diberi kekuasaan dalam negara itu tidak dapat menjalankan kekuasaan dengan jiwa

\footnotetext{
10 CFG. Sunaryati Hartono, Politik Hukum Menuju Satu Sistem Hukum Nasional, (Bandung: Alumni, |99|), 52.

" Hotma P. Sibuea, Kedudukan, Fungsi, Wewenang dan Tugas Dewan Perwakilan Daerah Dalam Struktur Ketatanegaraan Republik Indonesia, (Disertasi--Program Pascasarjana Fakultas Universitas Pelita Harapan, Karawaci-Tangerang, 2008), 293.
} 
perikemanusiaan dan keadilan, maka tak akan mungkinlah dicapai suatu negara hukum. ${ }^{12}$ Dengan demikian, setiap corak asas negara hukum yang dianut suatu negara akan tercermin dalam politik hukum, baik terkait pembentukan perundangan-undangan pidananya ataupun penegakan hukumnya. Di dalam asas negara hukum yang dianut akan memancarkan pandangan hidup dari bangsa tersebut, yang kemudian mewarnai konstitusi suatu negara dan menjadi penyanggah dari sistem hukum yang ada.

Pandangan hidup, dalam konteks ke-Indonesia-an adalah Pancasila, merupakan suatu kesepakatan bersama atau konsensus umum dari mayoritas masyarakat pada negara bersangkutan. Menurut Jimly Asshiddiqie, jika kesepakatan umum itu runtuh, maka runtuh pula legitimasi kekuasaan negara yang bersangkutan, dan pada gilirannya perang saudara (civil war) atau revolusi dapat terjadi. ${ }^{13}$ Secara teoretis, pandangan Jimly Asshiddiqie tersebut merupakan justifikasi terhadap posisi Pancasila dalam suatu pengkajian hukum.

Jauh sebelum pendapat Jimly Asshiddiqie tersebut, Cicero mengatakan bahwa hukum muncul dari masyarakat, namun yang perlu dipahami adalah aparat penegak hukum juga merupakan bagian dari masyarakat itu sendiri. ${ }^{14}$ Demikian pula dalam pandangan Mahzab Historis Hukum, yang dipelopori oleh Karl von Savigny (1799-1861) dan Maine (1822-1888), ajaran mengenai volgeist dipopulerkan oleh murid dari von Savigny yaitu G. Puchta, dimana dijelaskan bahwa hukum itu tumbuh bersama-sama dengan pertumbuhan rakyat, dan menjadi kuat bersama-sama dengan kekuatan dari rakyat, dan pada akhirnya hukum akan mati jika bangsa itu kehilangan kebangsaannya. Oleh karena itu, menurut Derita Prapti Rahayu, menegaskan bahwa hukum ada pada dasarnya selalu muncul sejak pertama kali masyarakat ada,

\footnotetext{
12 Sudargo Gautama, Pengertian Tentang Negara Hukum, (Bandung: Alumni, 1983), 6.

13 Jimly Asshiddiqie, Konstitusi dan Konstitusionalisme Indonesia, (Jakarta: Konstitusi Press, 20 I0), 21.

14 Achmad Ali, Menguak Teori Hukum (Legal Theory) dan Teori Peradilan (Judicialprudence) Termasuk Interpretasi Undang-Undang (Legisprudence), Volume I, (Jakarta: Kencana, 20 I 2), 82.
} 
yang ditandai oleh pembenturan kepentingan-kepentingan. ${ }^{15}$ Namun, makna tersebut, masih belum menggambarkan kompleksitas antara "societas" (masyarakat) dan "ius" (hukum). Tidak tergambarkan, pada saat Cicero, dan von Savigny (Pen), mengeluarkan statement tersebut, bagaimana intensif dan rumit kaitan antara keduanya. Oleh karena itu, menurut Hans-Georg Gadamer, berfilsafat tidak mulai dari titik nol, tetapi harus berfikir dan berbicara dengan bahasa yang sudah kita miliki sendiri. Maka, pernyataan bahwa filsafat itu sepenuhnya bebas prasangka adalah naif. Filsafat tidak mulai dari suatu tempat tertentu, tidak dari titik awal yang sudah bersifat subjektif, personal maupun dengan suatu perspektif tertentu. ${ }^{16}$

Berkaitan dengan penegakan hukum pada ranah hukum pidana, maka menurut Barda Nawawi Arief menyebutkan bahwa tidak ada artinya hukum pidana (KUHP) diganti/diperbaharui, apabila tidak dipersiapkan atau tidak disertai dengan perubahan ilmu hukum pidananya. ${ }^{17}$ Dengan kata lain, criminal law reform atau legal substance reform harus disertai pula dengan pembaharuan 'ilmu pengetahuan' tentang hukum pidananya (legal/criminal science reform). Bahkan harus disertai pula dengan pembaharuan budaya hukum masyarakat (legal culture reform) dan pembaharuan struktur atau perangkat hukumnya (legal structure reform).

Mengacu kepada kesulitan-kesulitan yang diungkapkan oleh CFG. Sunaryati Hartono, Bernard Arief Sidharta, Khudzaifah Dimyati dan Kelik Wardiono, upaya pendistilasian Pancasila ke dalam peraturan perundang-undangan merupakan hambatan utama yang patut diprioritaskan. Pancasila sebagai philosophie grondlags dari Bangsa Indonesia tentunya memiliki view yang berbeda dalam memandang seorang manusia Indonesia, bahkan manusia pada umumnya. Perlu diakui bahwa kemunculan

\footnotetext{
${ }^{15}$ Derita Prapti Rahayu, Budaya Hukum Pancasila, (Yogyakarta: Thafamedia, 20 I4), 15.

${ }^{16}$ E. Sumaryono, Hermeneutik. Sebuah Metode Filsafat..., 80.

17 Barda Nawawi Arief, Beberapa Aspek Kebijakan Penegakan dan Pengembangan Hukum Pidana, (Bandung: Citra Aditya Bakti, 1998), 133.
} 
Pancasila tidak dalam kenihilan, namun mendapat pengaruh dari berbagai macam pemikiran. Namun demikian, sebagai bagian dari filsafat timur, posisi intuisi dalam metode pemahaman terhadap sifat kemanusiaan menjadikan Pancasila sebagai suatu model falsafah yang bersifat filosofis-dogmatis-teologis.

Sebagai suatu filsafat, Pancasila memiliki objek kajiannya yaitu manusia Indonesia. Ketika berbicara mengenai pandangan Pancasila terhadap manusia, maka hakikatnya tidak akan terlepas dari pendapat Notonagoro yang menjelaskan bahwa manusia Indonesia adalah makhluk monopluralis, yaitu pertama, berdasarkan 'kedudukan kodrat', manusia Indonesia yang terdiri dari manusia sebagai makhluk pribadi berdiri sendiri sekaligus sebagai makhluk Tuhan; kedua, berdasarkan 'susunan kodrat' Manusia Indonesia, yang terdiri dari unsur raga dan unsur jiwa; ketiga, berdasarkan 'sifat kodratnya', manusia Indonesia, yang terdiri dari unsur individual dan unsur sosial. ${ }^{18}$

Cara berfikir demikian tentunya merupakan hal asing bagi ilmuwan hukum saat ini. Titik tolak pandangan hidup bangsa Indonesia adalah keyakinan bahwa manusia itu diciptakan dalam kebersamaan dengan sesamanya; individu dan kesatuan pergaulan hidupnya (masyarakat) merupakan suatu kedwitunggalan.19 Jadi, kebersamaan dengan sesamanya atau pergaulan hidup itu adalah unsur hakiki dalam eksistensi manusia. Unsur raga, rasa, dan rasio bersama-sama mewujudkan aspek individualisme dari manusia, dan unsur rukun mewujudkan aspek sosialitas dari manusia; aspek individualisme dan aspek sosialitas tersebut merupakan suatu kesatuan yang tidak dapat dipisahkan yang satu dari yang lainnya.

Asas kerukunan atau 'rukun', merupakan alat perlengkapan bagi manusia, selain 'raga', 'rasa', dan 'rasio', dalam kehidupan berkelompok, dan tidak sebagai makhluk yang terpisah satu sama lain, dan kemudian, karena sesuatu hal ingin hidup bersama,

\footnotetext{
${ }_{18}$ Notonagoro, Pancasila Secara IImiah Populer, (Djakarta: Pantjuran Tudjuh, I97 I), 94-I 05.

${ }^{19}$ Bernard Arief Sidharta, Refleksi Tentang Struktur Ilmu Hukum...., I73- 174.
} 
berdasarkan Asas Kekeluargaan yang merupakan inti jiwa dari Pancasila.

Dalam konteks asas kerukunan tersebut, maka dikarenakan hidup berkelompok itu baru ada manfaatnya kalau hidup dengan rukun, maka alat perlengkapan manusia ini hendak dinamakan unsur rukun dalam kehidupan manusia. Dengan demikian, maka manusia itu terdiri dari empat unsur ini, yakni: Raga, Rasa, Rasio dan Rukun. Dengan asas kerukunan inilah manusia akan mencapai kebahagiaan dalam kehidupannya. Kalau manusia Indonesia melihat tujuan hidup manusia adalah hidup bahagia seperti dibentangkan tadi, maka caranya mencari jalan untuk sampai hidup bahagia itu, jalan untuk mempergunakan alat-alat perlengkapan hidupnya sebaik-baiknya, ialah cara musyawarah, cara mufakat. Cara musyawarah atau mufakat ini sebagai cara memperoleh kebahagiaan mengandung arti, diakui adanya atau mungkin adanya perbedaan antara manusia yang hidup berkelompok itu dalam mencari jalan menuju hidup bahagia tadi. Mengakui adanya perbedaan ini berarti mengakui adanya perbedaan dalam kepribadian masing-masing manusia yang berkelompok itu. Dan dengan tidak menyatakan bahwa salah seorang; jadi pendapat salah seorang itu akan menguasai (pendapat) orang-orang lainnya, melainkan harus diadakan muyawarah, mufakat; maka menurut pemikiran Bangsa Indonesia itu kepribadian individu, tidak saja diakui, tetapi juga dilindungi. ${ }^{20}$

\section{Metode Paradigma Filsafat Hukum Pancasila}

Konsep ilmu hukum dan metodologi yang digunakan dalam suatu penelitian memainkan peran yang sangat signifikan, agar ilmu hukum beserta temuan-temuannya tidak terjebak dalam kemiskinan relevansi dan aktualitasnya. Mengingat, temuantemuan tersebut akan memberikan nuansa kemanusiaan bagi ilmu hukum dalam mengabdi pada kesejahteraan sosial. Namun,

${ }^{20}$ Achmad Suhardi Kartodiprodjo, et.al, Prof Mr. Soedirman Kartodiprodjo Tentang Pancasila Sebagai Pandangan Hidup Bangsa Indonesia, (unpublished), (Bandung/Jakarta: t.tp, 2009), 57-60. 
keluasan dari cakupan konsep ilmu hukum menyebabkan kesulitan untuk dipahami. Hal tersebut diperparah dengan perdebatan penggunaan metodologi yang tak pernah kunjung usai. Perdebatan tersebut disebabkan karena ilmu sosial merupakan genus dari ilmu hukum, sehingga perdebatan dalam metodologi ilmu sosial memberikan pengaruh terhadap ilmu hukum. ${ }^{21}$

Dengan demikian, pertentangan ini bukan hanya sekedar, apakah living law patut diakui ataukah tidak diakui saja, namun pada prinsipnya merupakan tarik menarik antara kajian yang berlandaskan kepada ilmu hukum dan ilmu sosial dalam memandang hukum. Sebagaimana diungkapkan oleh Philipus M. Hadjon dan Tatiek Sri Djatmiati, bahwa juris Indonesia yang ingin mengangkat derajat keilmuan hukum berusaha mengempiriskan ilmu hukum melalui kajian-kajian sosiologik. ${ }^{22}$ Hal ini yang menyebabkan kerancuan dalam usaha pengembangan ilmu hukum. Senada dengan pendapat tersebut, Peter Mahmud Marzuki juga melihat adanya usaha untuk menjadikan ilmu hukum sebagai kajian yang bersifat empiris dengan menggunakan analisa statistik dalam pemecahan masalah. ${ }^{23}$ Dengan demikian, maka seharusnya sebagaimana diungkapkan oleh Mochtar Kusumaatmadja dimana pendekatan ilmu hukum hendaknya menggunakan metoda analitis atau positivisme. ${ }^{24}$ Dimana dalam menangani ilmu hukum positif ini kita akan berurusan dengan ilmu yang normatif, artinya ilmu mengenai kaidah-kaidah bagaimana orang seharusnya berperilaku (das sollen) dalam masyarakat, bukan bagaimana sebenarnya mereka berperilaku (das sein) dalam masyarakat.

\footnotetext{
${ }^{21}$ Johnny Ibrahim, Teori \& Metodologi Penelitian Hukum Normatif..., 28.

22 Philipus M. Hadjon \& Tatiek Sri Djatmiati, Argumentasi Hukum, (Yogyakarta: Gadjah Mada University Press, 20I4), I.

${ }^{23}$ Peter Mahmud Marzuki, Pengantar IImu Hukum, (Jakarta: Kencana, 201 I), 88.

${ }^{24}$ Mochtar Kusumaatmadja dan Bernard Arief Sidharta, Pengantar Ilmu Hukum. Suatu Pengenalan Pertama Ruang Lingkup Berlakunya Ilmu Hukum. Buku I, (Bandung: Alumni, 20I3), 8.
} 
Guna merumuskan metode yang tepat bagi pengembanan ilmu hukum (pengembanan hukum teoretis) dan praktis ilmu hukum (pengembanan hukum praktis) dalam kenyataan kehidupan kemasyarakatan, maka perlu dipahami kegiatan ilmiah dari ilmu hukum itu sendiri.

Ilmu hukum atau dogmatik hukum adalah ilmu yang kegiatan ilmiahnya mencakup kegiatan menginventarisasi, memaparkan, menginterpretasi dan mensistematisasi dan juga mengevaluasi keseluruhan hukum positif yang berlaku dalam suatu masyarakat atau negara tertentu, dengan bersaranakan konsep-konsep, kategori-kategori, teori-teori, klasifikasi-klasifikasi, dan metode-metode yang dibentuk dan dikembangkan khusus untuk melakukan semua kegiatan tersebut, yang keseluruhan kegiatannya itu diarahkan untuk mempersiapkan upaya menemukan penyelesaian yuridik terhadap masalah hukum, baik mikro maupun makro, yang mungkin terjadi di dalam masyarakat. Sehingga, ilmu hukum secara langsung terarah untuk menawarkan alternatif penyelesaian yuridik terhadap masalah konkret. ${ }^{25}$

Dalam melakukan pengembanan ilmu hukum, maka harus melalui kegiatan ilmu hukum, yaitu tahap pemaparan yang berintikan interpretasi dan tahap sistematisasi terhadap material (bahan-bahan) hukum. Pada tahap sistematisasi material hukum kemudian dibagi menjadi 3 (tiga) tataran, yaitu tataran teknis, tataran teleologis, dan sistematisasi eksternal. Dimana pada sistematisasi eksternal ini memanfaatkan produk berbagai ilmu manusia, yang dikenal dengan metode interdisipliner atau transdisipliner. Kegiatan ilmu hukum tersebut di atas dipergunakan untuk menyelesaikan permasalahan pokok ilmu hukum yang didasarkan kepada objek kajiannya yaitu fakta kemasyatakatan dan kaidah hukum. Dalam proses, kedua aspek

${ }^{25}$ Sulistyowati Irianto \& Shidarta (Ed), Metode Penelitian Hukum. Konstelasi dan Refleksi, (Jakarta: Yayasan Obor \& JHMP-FHUI, 20 I3), I 42. 
itu berinteraksi atau harus diinteraksikan. ${ }^{26}$ Karena itu, putusan yang dihasilkan harus dapat ditempatkan dalam tatanan hukum yang berlaku dan ke dalam tatanan kemasyarakatan yang di dalamnya tatanan hukum itu merupakan salah satu subsistemnya, disebut sebagai sistematisasi-eksternal material hukum yang menjadi entry point bagi pendekatan deskriptif-nomologis dan masukan dari ilmu-ilmu manusia lainnya khususnya Ekonomi, Sosiologi, Antropologi, Politik dan Sejarah yang merupakan "ingredients" yang harus diolah menjadi "adonan" bagi pengembanan ilmu hukum untuk memproduksi proposisi yuridis dan teori hukum.

Dengan melaksanakan fungsi sistematisasi-eksternal, maka pengembanan ilmu hukum sudah dijalankan dengan mengacu kepada strategi ilmu sosial yang memungkinkan ilmu hukum itu menjadi hidup dan relevan terhadap dinamika kehidupan bermasyarakat dan bernegara, namun pengolahan akhir berbagai masukan ini tetap hanya dapat dilakukan dengan menggunakan metode normatif yang mengacu pada nilai dan kaidah. Bagaimanapun, ilmu hukum dalam pengembanannya selalu harus mengacu dan berintikan rasionalitas-nilai dan rasionalitasberkaidah tanpa mengabaikan rasionalitas-efesiensi dan rasionalitas-kewajaran. Dapat dikatakan sesungguhnya dalam pengembanan ilmu hukum itu sekaligus mengakomodasikan ke dalam dirinya yaitu sejarah hukum, sosiologi hukum, antropologi hukum, psikologi hukum dan teori keadilan. ${ }^{27}$

\section{Penutup}

Ilmu hukum memiliki sifat yang unik dan khas sebagai suatu sui generis. Setiap negara memiliki kekhasan sendiri yang mempengaruhi perkembangan ilmu hukumnya. Demikian pula di Indonesia dimana Pancasila adalah salah satu unsur yang mencirikan keunikan dan kekhasan tersebut. Mengacu kepada

\footnotetext{
${ }^{26}$ Bernard Arief Sidharta, IImu Hukum Indonesia..., I 48- 160.

${ }^{27}$ Bernard Arief Sidharta, IImu Hukum Indonesia..., 76.
} 
pandangan Notonagoro, bahwa Manusia Indonesia dalam pandangan Pancasila adalah manusia yang monopluralis. Dimana pandangan tersebut lebih mengutamakan aspek keseimbangan dari unsur-unsur yang secara kodratinya adalah berpasangan monodualis. Maka ilmu hukum sebagai ilmu positif mengandung sifat normatif yang dalam pengembanan praktisnya, bergerak berdasarkan strategi ilmu sosial. Oleh karena, tidak dapat dipungkiri ilmu hukum memiliki tujuan memberikan solusi alternatif penyelesaian masalah konkret dalam masyarakat. Penggunaan strategi ilmu sosial tersebut, bukanlah dimaksudkan untuk mengubah sifat normatif dari ilmu hukum. Namun, mengadopsi Pancasila sebagai paradigma (filsafat) hukum, maka ilmu hukum dalam kancahnya bergerak terhadap geisteswissenschaften tidak dimungkinkan menggunakan metodemetode sains.

\section{Daftar Pustaka}

Achmad Ali, Menguak Teori Hukum (Legal Theory) dan Teori Peradilan (Judicialprudence) Termasuk Interpretasi Undang-Undang (Legisprudence). Volume I, Jakarta: Kencana, 2012.

Achmad Suhardi Kartodiprodjo, et.al, Prof Mr. Soedirman Kartodiprodjo tentang Pancasila Sebagai Pandangan Hidup Bangsa Indonesia, (unpublished), Bandung/Jakarta: tanpa penerbit, 2009.

B. Salam, Filsafat Manusia. Antropologi Metafisika, Jakarta: Bina Aksara, 1988.

Barda Nawawi Arief, Beberapa Aspek Kebijakan Penegakan dan Pengembangan Hukum Pidana, Bandung: Citra Aditya Bakti, 1998.

------, RUU KUHP Baru. Sebuah Restrukturisasi/Rekonstruksi Sistem Hukum Pidana Indonesia, Semarang: Badan Penerbit UNDIP, 2012. 
Bernard Arief Sidharta, Refleksi Tentang Struktur Ilmu Hukum Sebuah Penelitian Tentang Fundasi Kefilsafatan dan Sifat Keilmuan Ilmu Hukum Sebagai Landasan Pengembangan Ilmu Hukum Nasional Indonesia, Bandung: Mandar Maju, 2009.

-------, Ilmu Hukum Indonesia. Upaya Pengembangan Ilmu Hukum Sistematik Yang Responsif Terhadap Perubahan Masyarakat, Yogyakarta: Genta Publishing, 2013.

CFG. Sunaryati Hartono, Politik Hukum Menuju Satu Sistem Hukum Nasional, Bandung: Alumni, 1991.

Derita Prapti Rahayu, Budaya Hukum Pancasila, Yogyakarta: Thafamedia, 2014.

E. Sumaryono, Hermeneutik. Sebuah Metode Filsafat, Yogyakarta: Kanisius, 1999.

E.S. Anshari, Wawasan Islam, Jakarta: CV. Rajawali, 1984.

J. Remmelink, Pengantar Hukum Pidana Materiil 1, Yogyakarta: Maharsa Publishing, 2014.

Jan Hendrik Rapar, Pengantar Filsafat, Yogyakarta: Kanisius, 2010.

Jan Gijssels dan Mark van Hoecke, Apakah Teori Hukum Itu? [Pent. Bernard Arief Sidharta], Penerbitan Tidak Berkala Nomor 3, Seri Dasar-Dasar Ilmu Hukum Nomor 3, Bandung: Laboratorium Hukum Fakultas Hukum Universitas Katolik Parahyangan, 2001.

Jimly Asshiddiqie, Konstitusi dan Konstitusionalisme Indonesia, Jakarta: Konstitusi Press, 2010.

Johnny Ibrahim, Teori \& Metodologi Penelitian Hukum Normatif, Malang: Bayumedia Publishing, 2007.

Khudzaifah Dimyati \& Kelik Wardiono, Paradigma Rasional Dalam Ilmu Hukum. Basis Epistemologis Pure Theory of Law Hans Kelsen, Yogyakarta: Genta Publishing, 2014.

Komariah Emong Sapardjaja, Ajaran Sifat Melawan Hukum Materiel Dalam Hukum Pidana Indonesia, Bandung: Alumni, 2002. 
Mochtar Kusumaatmadja dan Bernard Arief Sidharta, Pengantar Ilmu Hukum. Suatu Pengenalan Pertama Ruang Lingkup Berlakunya Ilmu Hukum. Buku I, Bandung: Alumni, 2013.

Notonagoro, Pancasila Ilmiah Populer, Jakarta: Semarang: CV. Pantjuran Tudjuh, 1971.

Otje Salman, Filsafat Hukum (Perkembangan dan Dinamika Masalah), Bandung: Refika Aditama, 2010.

Peter Mahmud Marzuki, Pengantar Ilmu Hukum, Jakarta: Kencana, 2011.

Philipus M. Hadjon \& Tatiek Sri Djatmiati, Argumentasi Hukum, Yogyakarta: Gadjah Mada University Press, 2014.

R. Soepomo, Bab-Bab Tentang Hukum Adat, Jakarta: Balai Pustaka, 2013.

Ria Casmi Arrsa, Deideologi Pancasila, Malang: UB Press, 2011.

Roeslan Saleh, Perbuatan Pidana dan PertanggungJawaban Pidana. Dua Pengertian Dasar Dalam Hukum Pidana, Jakarta: Aksara Baru, 1983.

Roeslan Saleh, Sifat Melawan Hukum Perbuatan Pidana, Jakarta: Aksara Baru, 1987.

Sudargo Gautama, Pengertian Tentang Negara Hukum, Bandung: Alumni, 1983.

Sulistyowati Irianto \& Shidarta (Ed), Metode Penelitian Hukum. Konstelasi dan Refleksi, Jakarta: Yayasan Obor \& JHMPFHUI, 2013.

Thomas Aquinas, Summa Theologia: Principles of Morality, London England: Eyre and Spottiswoode, 1996.

Paulus Hadisuprapto, Ilmu Hukum (Pendekatan Kajiannya), Makalah ini disajikan dalam acara Kuliah Umum (stadium generale) pada Program Magister Ilmu Hukum Universitas Jambi, 23 Mei 2009.

Hotma P. Sibuea, Kedudukan, Fungsi, Wewenang dan Tugas Dewan Perwakilan Daerah Dalam Struktur Ketatanegaraan Republik Indonesia, Disertasi Program Pascasarjana 
Fakultas Universitas Pelita Harapan, Karawaci-Tangerang, 2008.

F. Budi Hardiman, Dilthey dan Hermeneutika Ilmu-Ilmu SosialKemanusiaan, Makalah untuk kuliah kedua Kelas Filsafat Seni Memahami: Hermeneutika dari Schleiermacher sampai Gadamer, Serambi Salihara, 11 Februari 2014, 19:00 WIB.

-------, Gadamer Dan Hermeneutik Filosofis, Makalah untuk kuliah terakhir Kelas Filsafat Seni Memahami: Hermeneutika dari Schleiermacher sampai Gadamer, Serambi Salihara, Jakarta, 25 Februari 2014, 19:00 WIB.

Satjipto Rahardjo, Biarkan Hukum Mengalir, Jakarta: Kompas, 2007. 